\title{
Study of Chlorophyll Pigments in Beans (Phaseolus vulgaris) in terms of Heavy Metal Complexation with Various Forms of Sulfur, in Order to Reduce Their Toxicity
}

\author{
Lucia MIHALESCU ${ }^{1 *}$, Zorica VOȘGAN ${ }^{1}$, Oana MARE ROŞCA ${ }^{1}$, Monica MARIAN ${ }^{1}$, Anca DUMUTA ${ }^{1}$, Aurel \\ MAXIM $^{2}$, Mirela CORDEA ${ }^{2}$ \\ ${ }^{1}$ Department of Biology, Technical University of Cluj Napoca, North University Center of Baia Mare, \\ no.76, Victoriei Street, Romania \\ ${ }^{2}$ University of Agricultural Sciences and Veterinary Medicine, Cluj-Napoca, Romania \\ *Corresponding author: luciamihalescu@yahoo.com
}

Bulletin USAMV series Agriculture 72(2)/2015

Print ISSN 1843-5246; Electronic ISSN 1843-5386

DOI 10.15835/buasvmcn-agr: 11388

\begin{abstract}
In this paper we intended to find the effect of the complexation of heavy metals with various forms of sulfur on the content of chlorophyll pigments in dwarf beans (Phaseolus vulgaris var. Compressius ellipticus). The effect of two heavy metals, cadmium and respectively lead, in different concentrations, on the content of chlorophyll pigments in the leaves of beans plantlets, by extracting the pigments by the hot process. These were the variants: $\mathrm{V}_{1} \mathrm{Cd} 1 \mathrm{mg} / \mathrm{l}, \mathrm{V}_{2} \mathrm{Cd} 1 \mathrm{mg} / \mathrm{l}+100 \mathrm{mg}$ Cys, $\mathrm{V}_{3} \mathrm{Cd} 1 \mathrm{mg} / \mathrm{l}+100 \mathrm{mgK}_{2} \mathrm{SO}_{4}, \mathrm{~V}_{4} \mathrm{Cd} 50 \mathrm{mg} / \mathrm{l}, \mathrm{V}_{5} \mathrm{Cd} 50 \mathrm{mg} / \mathrm{l}+100 \mathrm{mg}$ Cys, $\mathrm{V}_{6}$ Cd 50mg/l+100mgK $\mathrm{SO}_{4}, \mathrm{~V}_{7} \mathrm{~Pb} 1 \mathrm{mg} / \mathrm{l}, \mathrm{V}_{8} \mathrm{~Pb} 1 \mathrm{mg} / \mathrm{l}+100 \mathrm{mg}$ Cys, $\mathrm{V}_{9} \mathrm{~Pb} 1 \mathrm{mg} / \mathrm{l}+100 \mathrm{mg} \mathrm{K}_{2} \mathrm{SO}_{4}, \mathrm{~V}_{10} \mathrm{~Pb} 50 \mathrm{mg} / \mathrm{l}, \mathrm{V}_{11} \mathrm{~Pb}$ $50 \mathrm{mg} / \mathrm{l}+100 \mathrm{mg}$ Cys, $\mathrm{V}_{12} \mathrm{~Pb} 50 \mathrm{mg} / \mathrm{l}+100 \mathrm{mg} \mathrm{K}_{2} \mathrm{SO}_{4}, \mathrm{~V}_{13}$ - control sample. Following the experimental research, we can state that the contents of chlorophyll pigments in leaves is negatively influenced by organic sulfur (cysteine) and positively influenced by inorganic sulfur $\left(\mathrm{K}_{2} \mathrm{SO}_{4}\right)$, towards inhibition and, respectively, stimulation. Cysteine inhibits with $7 \%$ at high concentration of $\mathrm{Cd}(50 \mathrm{mg} / \mathrm{l})$, and $\mathrm{K}_{2} \mathrm{SO}_{4}$ stimulates with $1.2 \%$ at the same concentration of $\mathrm{Cd}$. In case of $\mathrm{Pb}(1 \mathrm{mg} / \mathrm{l})$, cysteine inhibits it with $5 \%$, and inorganic sulfur with $1 \%$ less as the control. Inorganic sulfur in combination with high concentration of $\mathrm{Pb}$ stimulates the pigments production in leaves with $3 \%$ more than the control, and concentrated Cd inhibits it with $15 \%$.
\end{abstract}

Keywords: beans, chlorophyll, inhibit, stimulate, sulf.

\section{INTRODUCTION}

The eco-physiologists were always interested in knowing the characteristics of plants that inhabit soils with high concentrations of heavy metals (Dobrota et al., 1999). The object of intense research is the transfer of metals inside the trophic chains of plants - animals - humans (Onac, 2000). Heavy metals represent major targets of phytoremediation, a new branch of the vegetal physiology (Chanez et al., 1997).

\section{AIMS AND OBJECTIVES}

The aim of this paper was to trace the effect of the complexation of heavy metals with various forms of sulfur on the content of chlorophyll pigments in dwarf beans with elliptical forms. The objectives were based on the monitoring of two heavy metals, cadmium and respectively lead, in different concentrations, on the content of chlorophyll pigments in the leaves of beans plantlets. 
Tab.1. The content of chlorophyll pigments in the experimental variants

\begin{tabular}{cccc}
\hline Variant & Fresh mass & Extinction & Fresh substance $(\mathrm{mg} / \mathrm{g})$ \\
\hline $\mathrm{V} 1 \mathrm{Cd}(1 \mathrm{mg} / \mathrm{l})$ & 2.914 & 0.7219 & 11.26 \\
\hline $\mathrm{V} 2 \mathrm{Cd}(1 \mathrm{mg} / \mathrm{l})+\mathrm{Cys}$ & 3.077 & 0.6721 & 10.49 \\
\hline $\mathrm{V} 3 \mathrm{Cd}(1 \mathrm{mg} / \mathrm{l})+\mathrm{K}_{2} \mathrm{SO}_{4}$ & 2.907 & 0.7610 & 11.87 \\
\hline $\mathrm{V} 4 \mathrm{Cd}(50 \mathrm{mg} / \mathrm{l})$ & 2.757 & 0.6423 & 10.02 \\
\hline $\mathrm{V} 5 \mathrm{Cd}(50 \mathrm{mg} / \mathrm{l})+\mathrm{Cys}_{2}$ & 3.659 & 0.7020 & 10.95 \\
\hline $\mathrm{V} 6 \mathrm{Cd}(50 \mathrm{mg} / \mathrm{l})+\mathrm{K}_{2} \mathrm{SO}_{4}$ & 2.573 & 0.7617 & 11.89 \\
\hline $\mathrm{V} 7 \mathrm{~Pb}(1 \mathrm{mg} / \mathrm{l})$ & 2.506 & 0.7518 & 11.73 \\
\hline $\mathrm{V} 8 \mathrm{~Pb}(1 \mathrm{mg} / \mathrm{l})+\mathrm{Cys}$ & 2.454 & 0.7121 & 11.12 \\
\hline $\mathrm{V} 9 \mathrm{~Pb}(1 \mathrm{mg} / \mathrm{l})+\mathrm{K}_{2} \mathrm{SO}_{4}$ & 3.869 & 0.7422 & 11.57 \\
\hline $\mathrm{V} 10 \mathrm{~Pb}(50 \mathrm{mg} / \mathrm{l})$ & 2.387 & 0.7415 & 11.11 \\
\hline $\mathrm{V} 11 \mathrm{~Pb}(50 \mathrm{mg} / \mathrm{l})+\mathrm{Cys}_{2}$ & 3.412 & 0.7117 & 12.04 \\
\hline $\mathrm{V} 12 \mathrm{~Pb}(50 \mathrm{mg} / \mathrm{l})+\mathrm{K}_{2} \mathrm{SO}_{4}$ & 2.230 & 0.7717 & 8.74 \\
\hline V $13-\mathrm{Control} \mathrm{sample}$ & 3.871 & 0.7521 &
\end{tabular}

\section{MATERIALS AND METHODS}

A dwarf variety with elliptical beans (Phaseolus vulgaris var. Compressius ellipticus) was used. These were the variants: $\mathrm{V}_{1} \mathrm{Cd} 1 \mathrm{mg} / \mathrm{l}, \mathrm{V}_{2} \mathrm{Cd} 1 \mathrm{mg} / \mathrm{l}$ $+100 \mathrm{mg}$ Cys, $\mathrm{V}_{3} \mathrm{Cd} 1 \mathrm{mg} / \mathrm{l}+100 \mathrm{mgK}_{2} \mathrm{SO}_{4}, \mathrm{~V}_{4} \mathrm{Cd}$ $50 \mathrm{mg} / \mathrm{l}, \mathrm{V}_{5}$ Cd $50 \mathrm{mg} / \mathrm{l}+100 \mathrm{mg}$ Cys, $\mathrm{V}_{6} \mathrm{Cd} 50 \mathrm{mg} /$ $\mathrm{l}+100 \mathrm{mgK}_{2} \mathrm{SO}_{4}, \mathrm{~V}_{7} \mathrm{~Pb} 1 \mathrm{mg} / \mathrm{l}, \mathrm{V}_{8} \mathrm{~Pb} 1 \mathrm{mg} / \mathrm{l}+100 \mathrm{mg}$ Cys, $\mathrm{V}_{9} \mathrm{~Pb} 1 \mathrm{mg} / \mathrm{l}+100 \mathrm{mg} \mathrm{K}_{2} \mathrm{SO}_{4}, \mathrm{~V}_{10} \mathrm{~Pb} 50 \mathrm{mg} / \mathrm{l}$, $\mathrm{V}_{11} \mathrm{~Pb} 50 \mathrm{mg} / \mathrm{l}+100 \mathrm{mg}$ Cys, $\mathrm{V}_{12}$ Pb 50mg/l+100mg $\mathrm{K}_{2} \mathrm{SO}_{4}, \mathrm{~V}_{13}$ - control sample. We used the hot process of extracting the pigments from the leaves of each variant. The extinction was measured by a spectrophotometer.

\section{RESULTS AND DISCUSSION}

In Tab. 1 is shown the content of chlorophyll pigments in the 13 studied experimental variants.

From the obtained results we found that at low concentrations of $\mathrm{Cd}(1 \mathrm{mg} / \mathrm{l})$, cysteine inhibits the contents of chlorophyll with $11 \%$ less than in the control, and inorganic sulfur stimulates with 1.1\% more than in the control. Cysteine inhibits with $7 \%$ at high concentration of $\mathrm{Cd}(50 \mathrm{mg} / \mathrm{l})$, and $\mathrm{K}_{2} \mathrm{SO}_{4}$ stimulates with $1.2 \%$ at the same concentration of Cd. Concentrations of $\mathrm{Cd}(50 \mathrm{mg} / \mathrm{l})+$ inorganic sulfur mostly stimulate the generation of chlorophyll pigments with $1.2 \%$, and $\mathrm{Cd}(50 \mathrm{mg} / \mathrm{l})$ mostly inhibits with $15 \%$. In case of $\mathrm{Pb}(1 \mathrm{mg} / \mathrm{l})$, cysteine inhibits it with 5\%, and inorganic sulfur with $1 \%$ less as the control. Inorganic sulfur in combination with high concentration of $\mathrm{Pb}$ stimulates the pigments production in leaves with $3 \%$ more than the control, and concentrated $\mathrm{Cd}$ inhibits it with $15 \%$.

\section{CONCLUSION}

The contents of chlorophyll pigments in leaves is negatively influenced by organic sulfur (cysteine) and positively influenced by inorganic sulfur $\left(\mathrm{K}_{2} \mathrm{SO}_{4}\right)$, towards inhibition and, respectively, stimulation. The variant $\mathrm{Pb}(50 \mathrm{mg} / \mathrm{l})$ + organic sulfur presented maximum amount of chlorophyll in leaves, and the variant $\mathrm{Cd}(1 \mathrm{mg} / \mathrm{l})$ + inorganic sulfur presented a minimum amount of chlorophyll in leaves with $11 \%$ less than the control.

\section{REFERENCES}

1. Chanez RL, Malik M, Li YM, Brown SL, Brewer EP, Angle JS, Baker AJ (1997). Phytoremediation of soil metals. Curr. Opin. Biotec,h 8: 279-284.

2. Dobrota C, Yamashita M (1999). Cresterea si dezvoltarea plantelor. Ed. Gloria Cluj Napoca.

3. Onac S (2000). Consideratii generale privind influenta unor metale grele $(\mathrm{Cd}, \mathrm{Zn}, \mathrm{Pb}, \mathrm{Cu})$, asupra unor procese fiziologice la plante. Referat. Univ. Babes Bolyai, Cluj Napoca: 58-63. 